\title{
Challenging conventional views on mobile- telecommunications investment: Evidence from conflict zones
}

DOI:

10.1080/09614520902808290

Link to publication record in Manchester Research Explorer

Citation for published version (APA):

Konkel, A., \& Heeks, R. (2009). Challenging conventional views on mobile-telecommunications investment: Evidence from conflict zones. Development in Practice, 19(3), 414-420.

https://doi.org/10.1080/09614520902808290

\section{Published in:}

Development in Practice

\section{Citing this paper}

Please note that where the full-text provided on Manchester Research Explorer is the Author Accepted Manuscript or Proof version this may differ from the final Published version. If citing, it is advised that you check and use the publisher's definitive version.

\section{General rights}

Copyright and moral rights for the publications made accessible in the Research Explorer are retained by the authors and/or other copyright owners and it is a condition of accessing publications that users recognise and abide by the legal requirements associated with these rights.

\section{Takedown policy}

If you believe that this document breaches copyright please refer to the University of Manchester's Takedown Procedures [http://man.ac.uk/04Y6Bo] or contact uml.scholarlycommunications@manchester.ac.uk providing relevant details, so we can investigate your claim.

\section{OPEN ACCESS}


This is the post-peer reviewed final draft version of the following article: Konkel, A. \& Heeks, R.. "Challenging conventional views on mobile telecommunications investment: evidence from conflict zones", Development in Practice, 19(3), 414-420, 2009, which has been published in final form at:

http://www.tandfonline.com/doi/abs/10.1080/09614520902808290

\section{Challenging Conventional Views on Mobile Telecommunications Investment: Evidence from Conflict Zones}

\author{
Agnieszka Konkel \\ Polish-American Freedom Foundation \\ 72 Dobra Street \\ 00-312 Warsaw \\ Poland \\ Tel: +48-22-828-4373 \\ Email: agnes_konkel@hotmail.com
}

Agnieszka Konkel graduated from

Warsaw School of Economics, Aarhus

School of Business, and the University of

Manchester. Formerly working in the

Polish public sector and the European

Commission on the information society,

she now works for the Polish-American

Freedom Foundation.
\& Richard Heeks

Institute for Development Policy \&

Management

University of Manchester

Arthur Lewis Building

Manchester M13 9PL

UK

Tel: +44-161-275-2870

Email:

richard.heeks@manchester.ac.uk

*Corresponding Author

Richard Heeks is Chair in

Development Informatics at the University of Manchester, UK. He leads the MSc programme in ICTs for Development, and his research focuses on the role of ICTs in socioeconomic development.

\footnotetext{
Abstract

Huge amounts are being invested in information and communication technologies such as mobile phones and their telecommunications infrastructure. Development agencies provide a conventional view on the "climate" needed to encourage such investment; particularly that good governance and security are required. We question this conventional view with a study of mobile telecommunications in three insecure states that score very badly in the Worldwide Governance Indicators. Data is limited but suggests insecurity and "bad governance" may not be the barriers to investment that are normally supposed. Indeed, it is possible - at least for this type of digital technology - that they may encourage investment.
} 


\section{Introduction}

What do you need to facilitate investment in mobile telecommunications?

Mobile telecommunications has become a silver bullet $d u$ jour of international development. And, beyond the hype and alongside some exacerbation of inequities, it can be seen delivering both social and economic development outcomes (Heeks and Jagun 2007). Yet at least half the world's population lack access to this development tool.

Not surprisingly, then, there is significant interest in understanding those factors which can facilitate greater investment in mobile technology (and in information and communication technologies - ICTs - more broadly). Hence, the initial question. To which the standard answer has been that the "investment climate" - the factors that shape opportunities and incentives for investment - rests on a series of investment "pillars" (Mills and Fan 2006).

Those pillars are security and stability, finance and infrastructure, workers and labour markets, and the regulatory framework and tax. Overarching all of these, the view is that good, stable governance forms the crucial basis for investment. In its absence, investment will be curtailed. This conventional view, emanating from key international development agencies, is seen as similar whether considering developing countries generally (World Bank 2005) or those that have been conflict-affected (Mills and Fan 2006).

\section{The governance and security investment climate in three conflict zones}

We therefore decided to investigate further, picking out security and good governance as two key elements seen as necessary for facilitating investment, and looking at investment in mobile telecommunications in three countries that had neither during the initial years of the $21^{\text {st }}$ century: Afghanistan, Democratic Republic of Congo, and Somalia.

Measures of governance were assessed for the period up to 2006 via the Worldwide Governance Indicators (Kaufman et al. 2007). All three countries were in the bottom $10^{\text {th }}$ percentile rank (and, for most measures in the bottom $5 \%$ of countries worldwide) throughout the 2000s, and were listed as "governance crisis" countries. Their governance charts are shown in Figure 1 (developed from Kaufman et al. 2007). 

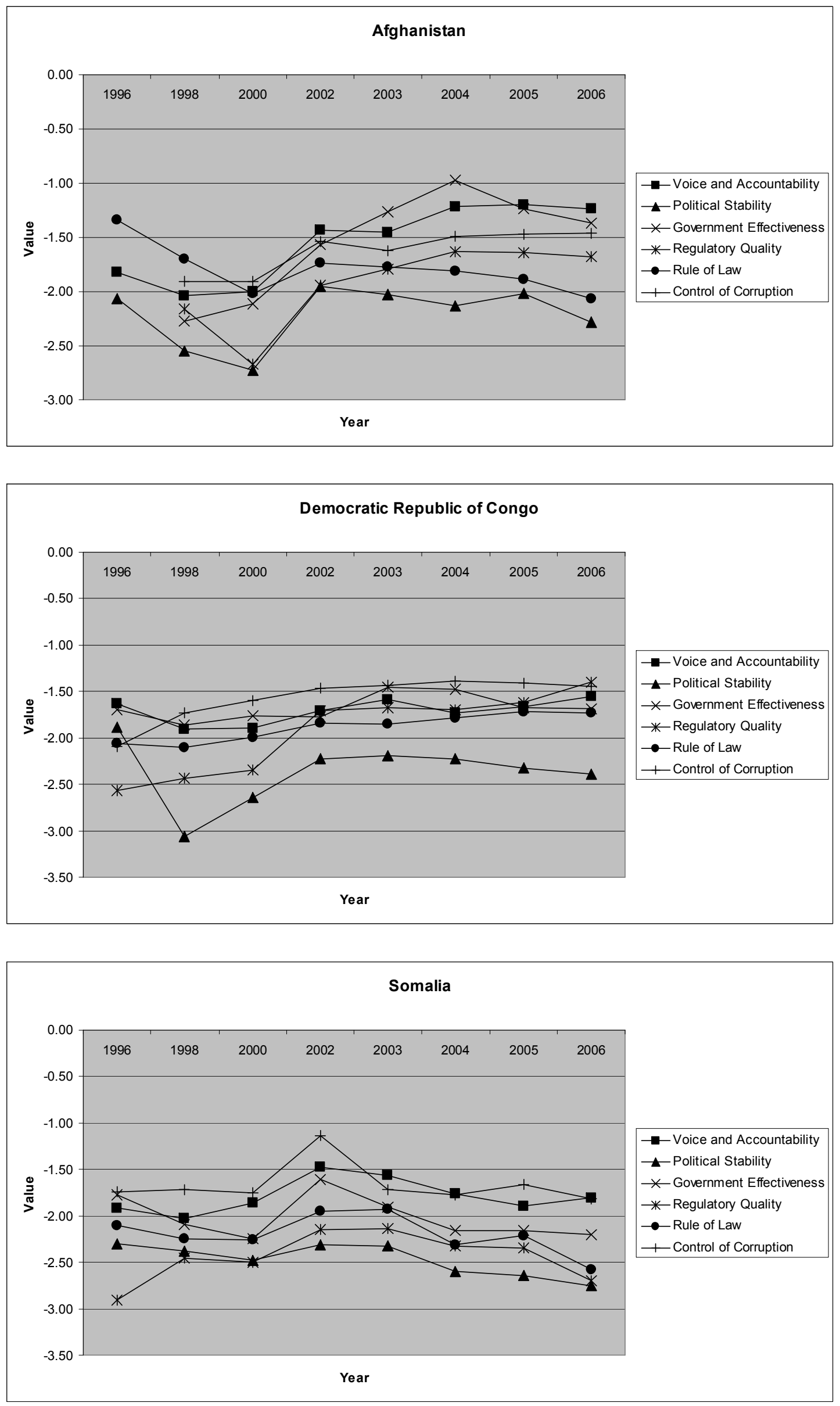
Figure 1 - Afghanistan, DRC and Somalia Governance Indicators

Indicators of security were a bit harder to identify. For all three countries, one could chart a continuing series of reports on armed conflict, killing of civilians and general insecurity throughout the 2000s (e.g. HRW 2000, MSF 2005). They were three of the five countries listed by the UN as violating children's rights in relation to armed conflict (HRW 2004). All three were sites of international peace-keeping interventions. And they were three of the six sites worldwide identified statistically as the most-violent and least-secure for aid operations (Stoddard et al. 2006). It therefore seems reasonable to conclude that - just as with governance - the three countries were among the bottom 5\% (and possibly the bottom 2\%) of countries worldwide in terms of security.

Given this, we may conclude that Afghanistan, Democratic Republic of Congo, and Somalia are investment "basket cases" according to conventional investment models. They were among the most insecure, violent, unstable, corrupt, unregulated, unlawful and generally ungoverned countries on earth. No-one in their right mind would ever invest in such places. Or would they?

\section{Investment in mobile telecommunications}

We have no direct figures for the level of investment. Therefore we have to rely on proxies. Looking at the period from the end of 2000, we find a plethora of mobile telecommunication company launches; all of which led on to investments that created active GSM networks as summarised in Table 1 (GSMA 2007):

\begin{tabular}{|l|l|l|}
\hline Launch Date & Country & Company \\
\hline December 2000 & DRC & Celtel Congo \\
\hline December 2000 & DRC & Oasis SPRL (SAIT Telecom) \\
\hline July 2001 & Somalia & Nationlink \\
\hline October 2001 & Somalia & Telsom Mobile Somalia \\
\hline December 2001 & DRC & Congo Chine Telecom \\
\hline December 2001 & DRC & Vodacom Congo (RDC) \\
\hline April 2002 & Afghanistan & Afghan Wireless Communication Company (AWCC) \\
\hline January 2003 & Somalia & Hormud Telecom Somalia \\
\hline June 2003 & Afghanistan & Telecom Development Company Afghanistan (ROSHAN) \\
\hline June 2003 & DRC & Supercell SPRL \\
\hline March 2005 & Somalia & Somafone FZLLC \\
\hline April 2005 & Somalia & Golis Telecommunication Company \\
\hline July 2006 & Afghanistan & Areeba Afghanistan \\
\hline
\end{tabular}

Table 1 - Mobile Investments in Conflict Countries

Arising from this investment, we see a rapid growth in mobile phone penetration, as shown in Figure 2 (from ITU 2006 and ITU 2008): 


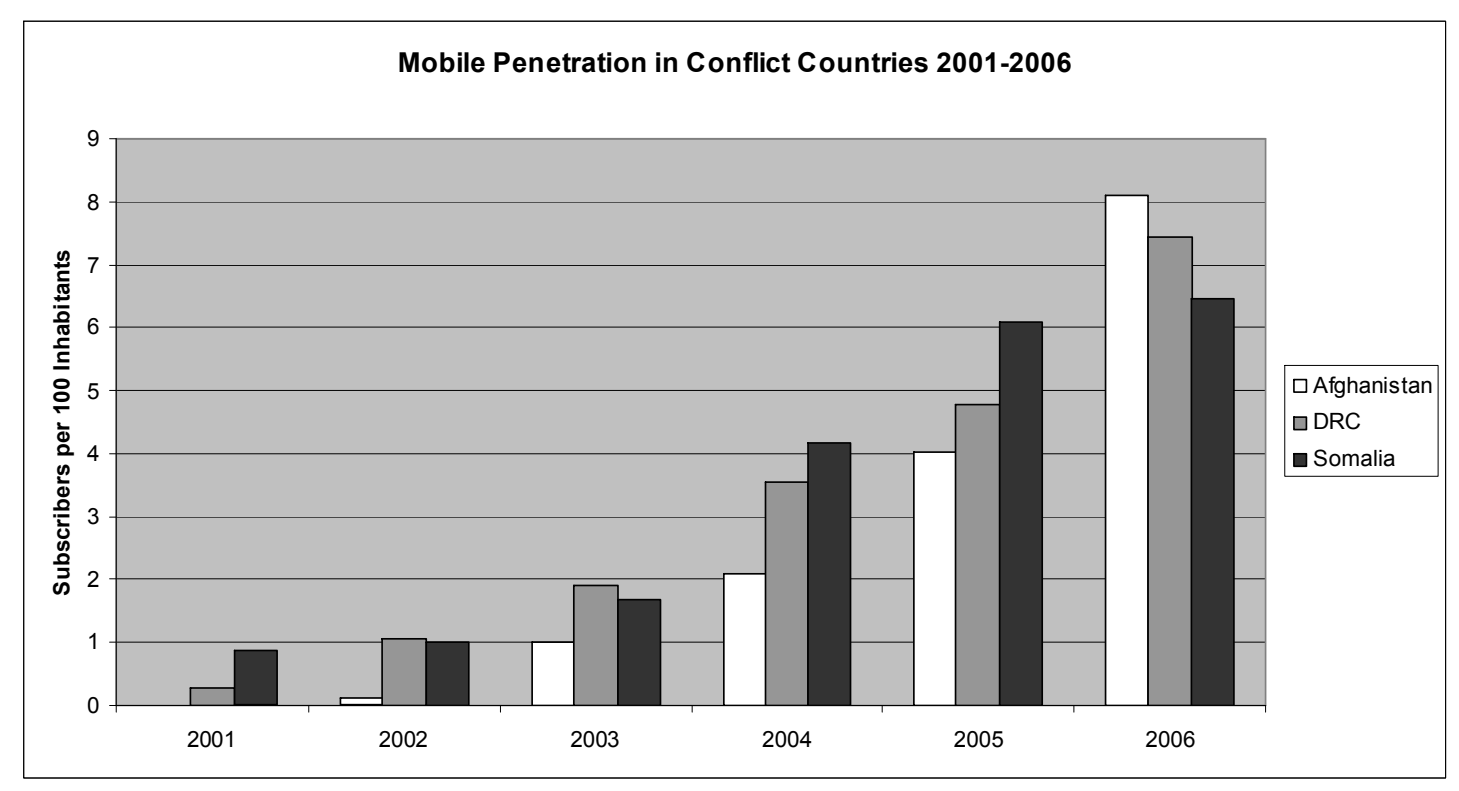

Figure 2 - Mobile Penetration in Conflict Countries

The average annual mobile penetration growth rate in the three countries from 20012006 was $111 \%$ (1). That compares to an average figure across Africa of $52 \%$ and across Asia of 28\% (ITU 2008). These countries are therefore outperforming the average.

We can add a few more "outperforming the average" tidbits in terms of the individual countries:

- Afghanistan: mobile telephony is acclaimed as "the most impressive economic success" (Middle East Times 2006). It had the third-highest growth rate in the world, pipped only by two other conflict-affected countries - Iraq and Liberia.

- Democratic Republic of Congo: $70 \%$ of the country had mobile coverage by the end of the period; a figure well above the average for Africa (Conteh 2006).

- Somalia: seen as the market leader in East Africa (Davis 2007), with belowaverage call costs following a price fall of some $90 \%$ in less than a decade (CIA 2007).

Of course, high growth rates could be put down to the very low baseline figures, and also the absence of mainline telephony alternatives. That may be part of the story but even here there is some balancing evidence. Afghanistan's 2002 mobile telephony baseline figure is regionally and continentally very low (of countries providing data only Myanmar, Nepal and Iraq scored lower in Asia). But DRC and Somalia's 2001 baselines are not dissimilar to much of sub-Saharan Africa - for example, they are both higher than the figure for Nigeria (ITU 2008).

Mainline telephony was in a parlous state in Afghanistan and DRC in 2001 - both registered declines from levels in the mid-1990s; and each was the lowest recorded on its continent. On the other hand, mainline penetration in Somalia was very much on a par with other sub-Saharan countries including, again, Nigeria. And 2001-2006 mainline penetration growth rates for Afghanistan and Somalia were among the highest continent-wide (Afghanistan was second-highest in Asia; Somalia was thirdhighest in Africa) (ibid.). 


\section{Conclusions}

What, then, can we conclude? First, that any conclusions must be tentative. We looked at only three countries; we have no direct figures on our key dependent variable - investment levels; and we have made use of only secondary, largely quantitative data. We also have limited evidence about the source of investment. Some is likely to come from aid flows; for example, the ITU had assistance programmes in all three countries during the 2000s. However, much more is likely to have come from foreign investment, particularly from non-resident citizens of the country (van Zant 2005).

The conventional wisdom says that insecurity deters investment. Our modest study finds no basis to support this statement in the case of mobile telecommunications investment. Investment has occurred despite significant insecurity and there are signs that it may have been higher than average in per capita terms. One might hypothesise why: insecure countries are places of great uncertainty, and uncertainty pushes up the value of information. Thus citizens will be willing to invest a greater-than-average amount of income on information and communication technologies; particularly those - like mobile phones - which can help provide just the kind of information (safe/unsafe locations, approaching dangers, places to find scarce commodities, etc) that addresses their main uncertainties.

This idea is supported by the finding that personal safety is a key driver behind diffusion of mobile telephony (Castells et al. 2007), and by other data: for example, the 2006 outbreak of violence in the Lebanon was associated with a $40 \%$ rise in mobile phone traffic (MTC 2006). We might also consider other drivers to mobile phone use in these countries: the military and quasi-military uses of mobile telephony; for example, to coordinate attacks; and uses to coordinate other illegal activities that tend to spring up in insecure situations (e.g. The Economist 2007). This partly explains why mobile telecommunications is much less likely to be targetted for attack than other parts of the infrastructure (Bray 2005).

The conventional wisdom says that "bad governance" deters investment. Again, our study finds no basis to support this in relation to mobile telecommunications investment. Investment has occurred despite a widespread breakdown in governance and there are signs that it may have been higher than average.

Three possible hypotheses come to mind. One is that the lure of high demand and profits may be sufficient to pull investors through the obstacles posed by bad governance (though some diaspora investors might also have been motivated by service-provision and nationalist purposes). The second is that, as with lack of security, lack of governance may create a premium for information and hence an investment premium for the tools - such as mobile phones - that handle information.

The third hypothesis is that "governance" presents more of a barrier to ICT investors than is normally supposed. Certainly, in Somalia - the least-governed of the three investment has gone ahead in the almost total absence of governance. Instead, the investors/mobile operators have self-organised; for example, sorting out their own interconnection between networks in a way often argued will only happen through the 
intervention of a government-appointed regulator (Vasquez 2005). They have therefore demonstrated that self-regulation can happen.

Finally, we note one other possible attraction for investment in insecure, barelygoverned countries: the level of competition may be less than in other countries; partly because of the level of insecurity and risk. Investors may therefore be able to invest at their own pace rather than be driven by forces of a well-functioning competitive market (Hale 2002).

In conclusion, we have neither the breadth nor depth of data here to overturn the entire applecart of conventional wisdom about investment. At best, we have "scrumped" a few of those apples. We have shown that significant investment does still occur in insecure countries with bad governance; at least in relation to some ICTs. We have suggested reasons why ICT investment could be higher-than-average in such countries. And we have questioned whether security and governance are quite so important as they are often made out as factors facilitating investment in mobiles and, perhaps, in other information- and communication-related tools of development.

\section{Notes}

(1) 2002-2006 for Afghanistan to avoid producing an infinite percentage result.

\section{References}

Bray, John (2005) International Companies and Post-Conflict Reconstruction, Social Development Papers No 22, Washington, DC: World Bank, available at http://go.worldbank.org/J923JUDPT0 (retrieved 24 July 2008).

Castells, Manuel, Mireia Fernandez-Ardevol, Jack Qiu, and Araba Sey (2007) Mobile Communication and Society, Cambridge, MA: MIT Press.

CIA (2007) The World Factbook. Somalia, Washington, DC: Central Intelligence Agency, available at https://www.cia.gov/library/publications/the-world-factbook/geos/so.html (retrieved 24 July 2008).

Conteh, Alieu (2006) Overcoming the Vast Challenge of Deploying a Mobile Network in the Democratic Republic of Congo, Washington, DC: World Bank.

Davis, Peter (2007) 'Politics: business in Somalia - stateless but not lawless: step forward anarchocapitalism', Ethical Corporation, 4 Apr, available at http://www.ethicalcorp.com/content.asp?ContentID=4994\&rss=41.xml (retrieved 24 July 2008).

GSMA (2007) GSM Coverage Maps and Roaming Information, Atlanta, GA: GSM Association, available at http://www.gsmworld.com/roaming/gsminfo/index.shtml (retrieved 3 Sept 2008).

Hale, Briony (2002) 'The hotspots of African investment', BBC News:Business, 25 Jun, available at http://news.bbc.co.uk/1/hi/business/2031423.stm (retrieved 24 July 2008).

Heeks, Richard and Abi Jagun (2007) Mobile Phones and Development: The Future in New Hands?, ID21 Insights Special Issue, no.69, available at http://www.id21.org/insights/insights69/insights69.pdf (retrieved 24 July 2008).

HRW (2000) Human Rights Watch World Report 2000, New York, NY: Human Rights Watch, available at http://www.hrw.org/wr2k/ (retrieved 24 July 2008).

HRW (2004) Human Rights Watch World Report 2004, New York, NY: Human Rights Watch, available at http://hrw.org/wr2k4/download/wr2k4.pdf (retrieved 24 July 2008). 
ITU (2006) ICT and Telecommunications in the Least Developed Countries, Geneva: International Telecommunication Union, available at http://www.itu.int/ITU-D/ldc/pdf/ictand telinldc-e.pdf (retrieved 24 July 2008).

ITU (2008) ICT Statistics Database, Geneva: International Telecommunication Union, available at http://www.itu.int/ITU-D/ICTEYE/Indicators/Indicators.aspx (retrieved 24 July 2008).

Kaufman, Daniel, Aart Kraay, and Massimo Mastruzzi (2007) Governance Matters V: Aggregate and Individual Governance Indicators for 1996-2005, Policy Research Working Paper 4012, Washington, DC: World Bank, available at http://info.worldbank.org/governance/wgi/resources.htm (retrieved 24 July 2008).

Middle East Times (2006) 'Afghanistan mobile operator enters market on auspicious note', Middle East Times, $25 \mathrm{Jul}$, available at http://www.metimes.com/storyview.php?StoryID=20060725-093111-5810r (retrieved 24 July 2008).

Mills, Rob, and Qimiao Fan (2006) The Investment Climate in Post-Conflict Situations, Research Working Paper No 4055, Washington, DC: World Bank.

MSF (2005) Voice from the Field, New York, NY: Medecins Sans Frontieres, available at http://www.doctorswithoutborders.org/news/article.cfm?id=1580 (retrieved 24 July 2008).

MTC (2006) MENA Region: Mobility for One Language, Diverse Cultures, Kuwait: Mobile Telecommunications Co, available at http://www.zain.com/muse/obj/portal/files/MTC\%20report/part1 (retrieved 24 July 2008).

Stoddard, Abby, Adele Harmer, and Katherine Haver (2006) Providing Aid in Insecure Environments, HPG Report 23, London: Overseas Development Institute, available at http://www.odi.org.uk/hpg/papers/hpgreport23.pdf (retrieved 24 July 2008).

The Economist (2007) 'Shining a light', The Economist, 8 Mar.

van Zant, Eric (2005) Tapping the Private Sector, Bangkok: Asian Development Bank, available at http://www.adb.org/Documents/Periodicals/ADB_Review/2005/vol37-6/private-sector.asp (retrieved 24 July 2008).

Vasquez, Vince (2007) 'Somalia: the rubble and the blossom', The Liberty 21(9), available at http://www.libertyunbound.com/archive/2007_09/vasquez-somalia.html (retrieved 24 July 2008).

World Bank (2005) World Development Report 2005, Washington, DC: World Bank, available at http://siteresources.worldbank.org/INTWDR2005/Resources/complete_report.pdf (retrieved 24 July 2008). 